\title{
Antinociceptive effects of epidural tramadol administration in dogs as an analgesic technique for experimental stifle surgery
}

\author{
Efeitos antinociceptivos da administração epidural de tramadol \\ em cães como técnica analgésica para cirurgia experimental do joelho \\ Cláudio Côrrea Natalini ${ }^{1}$, Alexandre da Silva Polydoro² \& Nadia Crosignani ${ }^{2}$
}

\begin{abstract}
Tramadol is a centrally acting analgesic with $\mu$-opioid and monoaminergic agonist effect. Ten healthy adult dogs were studied (mean \pm SEM body weight $17.3 \pm 3.8 \mathrm{~kg}$ ), premedicated with acepromazine $(0.05 \mathrm{mg} / \mathrm{kg}$, IM), induced with thiopental $(10 \mathrm{mg} / \mathrm{kg}, \mathrm{IV})$ and maintained under anesthesia with halothane in oxygen. Twenty minutes after starting halothane anesthesia, tramadol ( $1.0 \mathrm{mg} / \mathrm{kg}$ in $0.22 \mathrm{ml} / \mathrm{kg}$ of sterile water) was administered epidurally at the lumbo-sacral space. Surgery began 15 minutes later. Pulse and respiratory rates, systolic, mean and diastolic arterial blood pressure, and pulse oximetry were measured before premedication (baseline), and at fixed intervals after anesthesia induction. Arterial pH, $\mathrm{PaO}_{2}, \mathrm{PaCO}_{2}, \mathrm{HCO}_{3}^{-}$, and $\mathrm{SaO}_{2}$ were measured at baseline, immediately before the epidural, and 60, 120, 240 and 360 minutes thereafter. Post-operative analgesia was evaluated for four hours using a scoring system. Statistically significant decrease in arterial blood pressure was observed following anesthetic induction. The $\mathrm{PaCO}_{2}$ increased significantly from baseline at 60 minutes after epidural tramadol. The remaining variables were not significantly different from baseline values. No variables were significantly different from values obtained immediately before tramadol administration. Intraoperative antinociception was considered adequate, with satisfactory post-operative analgesia for four hours. In conclusion, epidural tramadol seems to produce satisfactory antinociception and analgesia without causing clinically significant hemodynamic and respiratory depression in healthy dogs undergoing stifle surgery.
\end{abstract}

Key words: Tramadol, epidural analgesia, canine, experimental surgery, experimental anesthesia.

\section{RESUMO}

O tramadol é um analgésico de ação cental com efeitos sobre receptores $\mu$-opióide e efeitos agonistas monoaminérgicos. Dez cães adultos hígidos foram estudados. (média \pm SD peso corpóreo, $17.3 \pm 3.8 \mathrm{~kg}$ ). Os animais foram premedicados com acepromazina $\left(0.05 \mathrm{mg} \cdot \mathrm{kg}^{-1}, \mathrm{IM}\right)$, induzidos com tiopental $\left(10 \mathrm{mg}^{\mathrm{kg}}{ }^{-1}, \mathrm{IV}\right)$ e mantidos com halotano em oxigênio. Vinte minutos após o início da anestesia com halotano, tramadol $\left(1.0 \mathrm{mg} \cdot \mathrm{kg}^{-1} \mathrm{em} 0.22 \mathrm{ml} \cdot \mathrm{kg}^{-1}\right.$ de água destilada) foi administrao por via epidural no espaço lombo-sacro. A cirurgia iniciou-se 15 minutos após. As freqüências de pulso e respiração, as pressões arteriais sistólica, média e diastólica, e a oximetria de pulso foram mensuradas antes da premedicação (valor basal), e em intervalos regulares após a indução anestésica. Valors arteriais de pH, $\mathrm{PaO}_{2}, \mathrm{PaCO}_{2}, \mathrm{HCO}_{3}^{-}, \mathrm{e} \mathrm{SaO}_{2}$ foram mensurados antes e imediatamente antes da administração epidural, e aos 60, 120, 240 e 360 minutos. A analgesia foi avaliada por 4 horas através de uma sistema de gradação. Redução estatisticamente significativa na pressão arterial sangüínea foi observada após a indução anestésica. $\mathrm{A} \mathrm{PaCO}_{2}$ aumentou significativamente dos valores basais e aos 60 minutos após a administração epidural de tramadol. As demais variáveis mantiveram-se sem diferenças significativas dos valores basais. A antinocicepção intraoperatória foi considerada adequada, com analgesia pós-operatória por 4 horas. Conclui-se que a administração epidural de tramadol produz antinocicepção e analgesia sem causar variações hemodinâmicas e respiratórias em cães hígidos submetidos a cirurgia de joelho.

Descritores: tramadol, analgesia epidural, caninos, cirurgia experimental, anestesia experimental. 


\section{INTRODUCTION}

Tramadol was introduced in Germany in the late 1970s [4,11]. It is an $\mu$-opioid receptor agonist with an analgesic potency equal to meperidine and 5 to 10 times less than morphine in humans [8]. Tramadol inhibits the neuronal uptake of norepinephrine and serotonin $[9,10,25]$. Studies have shown that tramadol also has local anesthetic action by producing analgesia after intradermal injection [1,23], or by reducing pain associated with propofol administration [22,31].

Racemic tramadol inhibits the synaptosomal uptake of norepinephrine and serotonin. The (+) enantiomer inhibits serotonin uptake, enhances serotonin release and has modest affinity for $\mu$-opioid receptors. The (-) enantiomer inhibits norepinephrine uptake They also interact in a complementary and synergistic manner to produce antinociception, but do not summate to increase side effects such as constipation and respiratory depression [24]. The pharmacological profile of tramadol makes it an attractive drug for epidural administration as an analgesic technique for surgeries in the hind limbs of dogs. Activation of opioid receptors, inhibition of the monoaminergic system and local anesthetic effects $[1,8,24]$, are likely to decrease transmission and improve modulation of afferent nociceptive signals, resulting in significant analgesia. These possibilities along with a shortage of informations on the epidural use of tramadol in the veterinary literature motivated this study. Therefore, the pre-operative epidural administration of tramadol was evaluated as an analgesic technique in dogs submitted to stifle surgery.

\section{MATERIALS AND METHODS}

The study was approved by the Scientific Committee of the Agricultural Center, Universidade Federal de Santa Maria, RS, Brazil. Ten adult, clinically healthy, mixed breed dogs, 6 male and 4 female, weighing $17.3 \pm 3.8 \mathrm{~kg}$ (mean $\pm \mathrm{SEM}$; range $=12$ to $23 \mathrm{~kg}$ ) were studied. The dogs were fasted for 12 hours and deprived of water for two hours preoperatively. The surgical procedure consisted of experimental excision and replacement of the cranial cruciate ligament in the right limb of each dog.

Acepromazine $^{1}$ was given intramuscularly as premedication $(0.05 \mathrm{mg} / \mathrm{kg})$, with the induction of anesthesia performed 15 minutes later with thiopen$\operatorname{tal}^{2} 10 \mathrm{mg} / \mathrm{kg}$ given intravenously through a catheter previously placed in the cephalic vein. Following tracheal intubation, halothane ${ }^{3}$ was delivered in $100 \%$ oxygen for anesthetic maintenance, using a semi-closed circle system with a fresh gas flow rate of $30 \mathrm{ml} / \mathrm{kg} / \mathrm{min}$. The animals were allowed to breathe spontaneously, and body temperature was maintained in the physiological normal range with the use of an electric warm blanket.

Twenty minutes following anesthetic induction, $1.0 \mathrm{mg} / \mathrm{kg}$ of tramadol ${ }^{4}$, diluted in distilled water to a final volume of $0.22 \mathrm{ml} / \mathrm{kg}$, was administered epidurally at the lumbo-sacral space. The dosage rate of tramadol ${ }^{4}$ chosen was determined as $1 / 10$ of the systemic dosage used in humans. The technique was performed using a 22 gauge, $3.75 \mathrm{~cm}$ spinal needle. Correct placement of the spinal needle in the epidural space was confirmed by the hanging drop technique and by the lack of resistance to administration of $1 \mathrm{ml}$ of air. The dogs remained laterally recumbent with the surgical side down for 10 minutes before being positioned dorsally for surgery. Lactate Ringer's solution was used intra-operatively at a rate of $20 \mathrm{ml} / \mathrm{kg} / \mathrm{h}$ for the first hour and $10 \mathrm{ml} / \mathrm{kg} / \mathrm{h}$ thereafter.

Arterial blood pressure (systolic, mean and diastolic), pulse rate, respiratory rate, arterial blood oxygen saturation, and arterial blood gases were evaluated. These measurements were taken in the conscious dog before any drug administration (baseline) and after anesthetic induction at 5, 10, 20, 30, 40, 50, 60, 70, 80, 90, 100 and 110 minutes. Arterial blood pressure was measured non-invasively by oscillometry ${ }^{5}$, with an appropriate cuff (width approximately equal to $40 \%$ of the limb circumference) positioned proximally to the carpus. Pulse rate and arterial blood oxygen saturation were obtained with a pulse oximeter ${ }^{6}$. The oximeter probe was placed on the lip, vulva or prepuce for the baseline, and on the tongue for intraoperative measurements. Respiratory rate and vaporizer settings (after anesthetic induction) were assessed at these same intervals.

Blood gas analyses ${ }^{7}$ were carried out to determine arterial partial pressures of oxygen $\left(\mathrm{PaO}_{2}\right)$ and carbon dioxide $\left(\mathrm{PaCO}_{2}\right)$, oxygen-hemoglobin saturation $\left(\mathrm{SaO}_{2}\right), \mathrm{pH}$ and plasma bicarbonate concentration $\left(\mathrm{HCO}_{3}^{-}\right)$. These parameters were measured before premedication (baseline), immediately before the epidural administration of tramadol (before epidural), and then 60, 120, 240 and 360 minutes after the epidural procedure. Blood from the femoral artery was collected anaerobically and immediately stored in ice water, with the evaluation carried out within a period of one hour. 
The vaporizer settings were adjusted to provide an adequate depth of surgical anesthesia. Presence or absence of limb movement, palpebral reflex and any detectable response to surgical stimulation were among the clinical parameters used to assess the depth of anesthesia. Based on this evaluation, dogs were allowed to be as lightly anesthetized as possible during the surgical procedures. Fentanyl $(2.5 \mathrm{mg} / \mathrm{kg}$ intravenously) was reserved for intraoperative administration to improve antinociception if necessary. The criteria for administration was based on an increase in pulse rate, mean arterial blood pressure and/or respiratory rate equal or higher than $15 \%$ of the previous value after the start of surgery, in the presence of an adequate depth of anesthesia. At the end of the anesthesia, duration of anesthetic recovery was measured from the time that the vaporizer was turned off to the moment that the dog assumed sternal position.

Post-operative analgesia was evaluated by an investigator (SA) unaware of the drug used epidurally, with the use of a scoring system designed for this study (Appendix A). Baseline assessments for pulse rate, respiratory rate, levels of vocalization, activity, posture, and color of mucous membranes were performed in each dog before the administration of any drug. These assessments were repeated in the post-operative period at 60, 120 and 240 minutes. Fifty percent increase in pulse or respiratory rate over baseline and/ or a total score of subjective assessments equal or greater than 3 points was assumed to be indicative of pain that should be treated with additional analgesics (morphine $0.5 \mathrm{mg} / \mathrm{kg}$ intramuscularly, repeated after 20 minutes as needed). After this 4-hour period, all dogs received $1.0 \mathrm{mg} / \mathrm{kg}$ of flunixin meglumine intravenously, which was continued for two additional days, administered subcutaneously every 24 hours.

Statistical analysis was performed using repeated measures analysis of variance to assess changes over time, followed by Bonferroni multiple comparison test when a significant difference was indicated. Differences were considered significant when $P<0.05$ and the data are reported as mean \pm standard error of the mean (SEM). The SEM bars and the indications of statistical significance were omitted from the charts for easier interpretation.

\section{RESULTS}

Duration of anesthesia and surgery were 100.2 \pm 11.2 and $77.5 \pm 7.5$ minutes, respectively. Duration of anesthetic recovery was $81.1 \pm 21.7$ minutes. The surgical conditions were considered very good, with good muscle relaxation, and no excessive bleeding. Intraoperative use of fentanyl was not necessary based on the chosen criteria. Vaporizer settings were significantly decreased over time (Figure 1). Values for pulse and respiratory rates, systolic, and diastolic arterial blood pressure, and pulse oximetry were within normal limits for dogs throughout the experiment.

\begin{tabular}{|c|c|}
\hline Clinical Sign & Score and Patient Criteria \\
\hline Vocalization & $\begin{array}{l}0=\text { None } \\
1=\text { Present, easily controllable by talking to the animal with a calm voice. } \\
2=\text { Present, controllable with gentle touch and calm voice. } \\
3=\text { Present, not controllable with gentle touch and calm voice. }\end{array}$ \\
\hline Level of activity & $\begin{array}{l}0=\text { Asleep, inactive or calm. } \\
1=\text { Uncomfortable, changing position constantly. } \\
2=\text { Agitated, constantly standing up and laying down. } \\
3=\text { Thrashing and destructive behavior. }\end{array}$ \\
\hline Posture & $\begin{array}{l}0=\text { Standing spontaneously and weight bearing. } \\
1=\text { Standing spontaneously, but non weight bearing. } \\
2=\text { Recumbent, but able to stand with verbal stimulation, with or without minimal help. } \\
3=\text { Recumbent, refuse to stand with verbal stimulation or minimal help. }\end{array}$ \\
\hline Mucous membrane coloration & $\begin{array}{l}0=\text { Normal coloration } . \\
1=\text { Pale mucous membrane }\end{array}$ \\
\hline Total Score Possible & 10 points \\
\hline
\end{tabular}


Induction of general anesthesia produced a statistically significant decrease in arterial blood pressure although hypotension (mean arterial blood pressure less than $70 \mathrm{mmHg}$ ) was not observed. $\mathrm{PaO}_{2}, \mathrm{PaCO}_{2}$, and arterial oxygen-hemoglobin saturation increased significantly from baseline during anesthesia, while they were similar to baseline in the post-operative period (120, 240 and 360 minutes after epidural tramadol). None of the cardiovascular and respiratory variables measured were changed with the epidural administration of tramadol.

The post-operative pain assessment showed that the dogs were apparently comfortable and these data are displayed on Table 1. In the subjective evaluation, all dogs showed no vocalization, were inactive or sleeping, and presented normal mucous membrane coloration throughout four hours of evaluation. For posture, most of the dogs were recumbent in the first hour, while in the second and fourth hours most of them were standing spontaneously, although not weight bearing on the operated limb. None of the dogs had fifty percent increase in heart or respiratory rate over baseline nor received a total score equal or greater than 3 points, and therefore no additional analgesics were used during the four hours of evaluation.

\section{DISCUSSION}

In humans, tramadol has been used epidurally for many years, but in veterinary medicine the epidural administration was studied only recently in horses, where tramadol was found to be 10 times less potent than morphine $[3,6,18]$. To date, there are no reports on the epidural administration of tramadol in dogs. Therefore the dose chosen for this study was based on human literature, where tramadol was used epidurally in children at doses of 1.0 to $2.0 \mathrm{mg} / \mathrm{kg}$, and from the study done in horses where it was administered at a dose of $1.0 \mathrm{mg} / \mathrm{kg}[3,27]$. Also, as tramadol was ten times less potent than morphine, the use of $1.0 \mathrm{mg} / \mathrm{kg}$ in the present study is likely to be equipotent with the dose of $0.1 \mathrm{mg} / \mathrm{kg}$ of morphine commonly used epidurally in dogs [18].

In this study, a decrease in arterial blood pressure, mild hypoventilation and decrease in respiratory rate were observed with the institution of general anesthesia as compared to the baseline values in the conscious animals. This is expected to happen with all the commonly used inhalant anesthetics, as they cause dose dependent cardiovascular and respiratory depression [28,29]. Tramadol was given epidurally after 20 minutes of general anesthesia, and no changes in arterial blood pressure, pulse and respiratory rates,

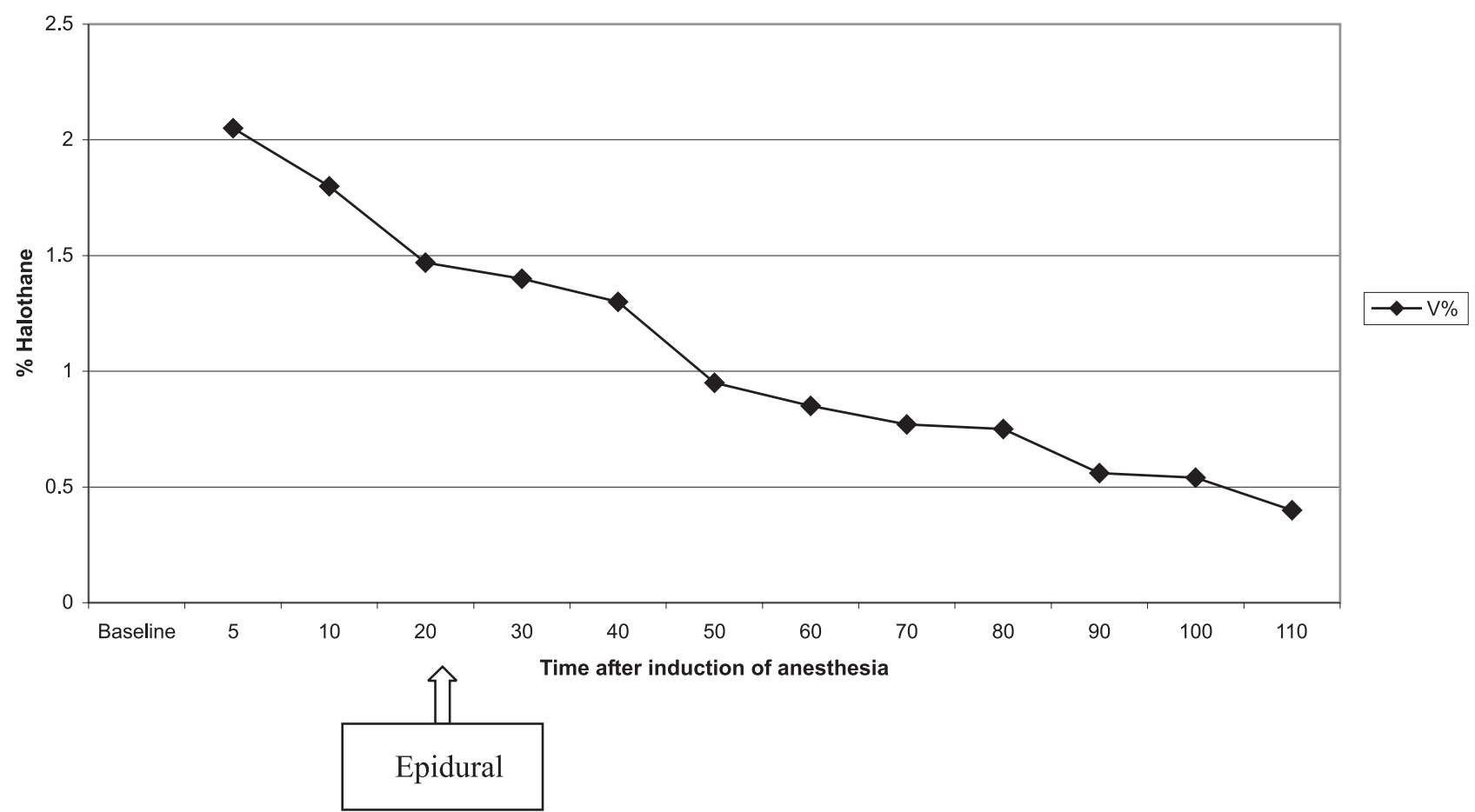

Figure 1. Intraoperative halothane vaporizer settings in dogs $(\mathrm{n}=10)$ given epidural tramadol $(1.0 \mathrm{mg} / \mathrm{kg})$ and submitted to stifle surgery. 
Table 1. Mean \pm standard error of the mean of pulse (PR) and respiratory $(f)$ rates, and scores used for pain evaluation during four hours of post-operative period, in dogs $(n=10)$ submitted to orthopedic surgery and epidural administration of tramadol $(1.0 \mathrm{mg} / \mathrm{kg})$.

\begin{tabular}{|c|c|c|c|c|c|c|}
\hline \multirow[b]{2}{*}{ Time } & \multicolumn{6}{|c|}{ Variables } \\
\hline & PR (pulses/min) & $f$ (breaths/min) & Vocalization $^{\dagger}$ & Activity $^{\dagger}$ & Posture $^{\dagger}$ & $\begin{array}{c}\text { Mucous } \\
\text { membrane color }{ }^{\dagger}\end{array}$ \\
\hline Baseline & $94.5 \pm 5.53^{a}$ & $23.4 \pm 4.48^{\mathrm{a}}$ & $0(n=10)$ & $0(n=10)$ & $0(n=10)$ & $0(n=10)$ \\
\hline $60^{*}$ & $119.2 \pm 9.74^{b}$ & $14.6 \pm 1.41^{\mathrm{b}}$ & $0(n=10)$ & $0(n=10)$ & $\begin{array}{l}1(n=1) \\
2(n=9)\end{array}$ & $0(n=10)$ \\
\hline $120^{*}$ & $101.2 \pm 7.49^{a b}$ & $15.0 \pm 1.21^{\mathrm{ab}}$ & $0(n=10)$ & $0(n=10)$ & $\begin{array}{l}1(n=6) \\
2(n=4)\end{array}$ & $0(n=10)$ \\
\hline $240^{*}$ & $113.7 \pm 6.23^{\mathrm{ab}}$ & $14.6 \pm 0.83^{b}$ & $0(n=10)$ & $0(n=10)$ & $\begin{array}{l}1(n=9) \\
2(n=1)\end{array}$ & $0(n=10)$ \\
\hline
\end{tabular}

pulse oximetry and arterial blood gases were noticed. Similar results have been observed in anesthetized humans and in unanesthetized horses after epidural administration of tramadol $[2,14,18,27,30]$. Additionally, intravenous doses up to $2.0 \mathrm{mg} / \mathrm{kg}$ in conscious humans, and up to $10 \mathrm{mg} / \mathrm{kg}$ in awake or anesthetized dogs had no significant adverse cardiovascular effects [16,19].

While inhalant anesthetics cause unconsciousness and the patient does not experience pain, even profound planes of anesthesia may not block nociception and many of the autonomic responses related to surgical stimulation [15]. Although clinical evaluation of adequate intraoperative antinociception may be difficult, tachypnea, tachycardia and hypertension may be observed in anesthetized animals in response to surgical stimulation [13]. Attempts to block these responses by increasing the volatile anesthetic concentration will result in severe respiratory depression [15]. None of these changes were observed in the present study. The anesthetic depth was maintained as light as possible, with most dogs showing palpebral reflexes and some degree of shivering in the second half of the anesthetic procedure, yet surgical conditions were good. Vaporizer settings remained below $1.0 \%$ for the surgical period 30 minutes after epidural administration of tramadol to the end of anesthesia, in the present study, with values similar or even lower than the reported minimum alveolar concentration of $0.87 \%$ for halothane in dogs [28]. A control group receiving epidural saline or sterile water was not studied for comparison as the authors considered not ethic nor necessary as based on an anthropomorphism for pain.

Noradrenergic descending pathways and the serotonergic system innervate all levels of the spinal cord, and can modulate afferent pain signals at this level [26,32]. Opioids, noradrenergic and serotonergic drugs can interact with these systems to produce antinociception, and the use of these drugs in combination improves analgesia significantly $[5,7,12,32]$. This may explain the antinociception obtained with the use of epidural tramadol as its opioid and monoaminergic actions interact at the level of the spinal cord to produce antinociception $[24,25]$.

The opioid and monoaminergic actions of tramadol are well recognized, and local anesthetic effects have also been demonstrated more recently. The intravenous regional administration of tramadol was shown to reduce the incidence of the painful sensation associated with intravenous administration of propofol in humans [22,31]. Also in humans, intradermal injection of tramadol produced loss of sensation to pin prick, light touch and cold in one study, and surgical analgesia similar to prilocaine in another $[1,23]$. Local anesthetic effects, combined with the opioid and monoaminergic actions, support the findings of satisfactory antinociception obtained in the present study.

The use of scores to evaluate the analgesic status of animals may not be accurate in some occasions due to the subjective and complex nature of pain [17]. However, pale mucous membranes due to peripheral vasoconstriction, tachypnea, and tachycardia may occur as a sympathetic response to pain 
in conscious animals $[13,17]$. Changes in respiratory rate are good physiologic indicators of pain with a high correlation with subjective methods of evaluation. Furthermore, a patient that is pain free will be calm, quiet and will often sleep [17]. In the present study, respiratory rate during the post-operative period remained similar or lower than baseline, and the animals were quiet, calm or asleep, indicating satisfactory post-operative analgesia. Several reports from the human literature have shown effective postoperative analgesia after epidural administration of tramadol $[2,3,20,27]$. In addition, complete analgesia in the perineal and sacral areas for four hours has been reported in horses given tramadol epidurally [18]. Our study suggests that the epidural administration of tramadol may produce at least approximately 5.5 hours of analgesia in dogs.
In conclusion, epidural tramadol produces satisfactory intraoperative antinociception and postoperative analgesia without causing clinically significant hemodynamic and respiratory depression in healthy dogs undergoing stifle surgery. This technique is recommended whenever experimental model for stifle surgery is studied in dogs as it does confer preemptive pain management.

\section{SOURCES AND MANUFACTURERS}

\author{
${ }^{1}$ Acepran 1\%, Andrômaco, São Paulo, SP, Brazil \\ ${ }^{2}$ Thionembutal, Abbott, São Paulo, SP, Brazil \\ ${ }^{3}$ Fluothane,Wellcome-Zeneca, Cotia, SP, Brazil \\ ${ }^{4}$ Tramal 50, Carlo Erba, Duque de Caxias, RJ, Brazil \\ ${ }^{5}$ Dinamap-Critikon, Tampa, FL, USA \\ ${ }^{6}$ Nellcor N-200, Nellcor Inc., Pleasanton, CA, USA \\ ${ }^{7}$ AVL AG900, Biomedical Instruments, Switzerland
}

\section{REFERENCES}

1 Altunoaya H., Ozer Y., Kargi E. \& Babuccu O. 2003. Comparison of local anaesthetic effects of tramadol with prilocaine for minor surgical procedures. British Journal of Anaesthesia. 90: 320-322.

2 Baraka A., Jabbour S., Ghabash M., Nader A., Khoury G. \& Sibai,A. 1993. A comparison of epidural tramadol and epidural morphine for postoperative analgesia. Canadian Journal of Anaesthesia. 40: 308-313.

3 Batra Y.K., Prasad M.K., Arya V.K., Chari P. \& Yaddanapudi L.N. 1999. Comparison of caudal tramadol vs bupivacaine for post-operative analgesia in children undergoing hypospadias surgery. International Journal of Clinical Pharmacology and Therapeutics. 37: 238-242.

4 Besson J.M. \& Vickers M.D. 1994. Tramadol Analgesia: Synergy in research and therapy. Drug. 47: 1-2.

5 Branson K.R., Ko J.C.H., Tranquilli W.J., Benson J. \& Thurmon J.C. 1993. Duration of analgesia induced by epidurally administered morphine and medetomidine in dogs. Journal of Veterinary Pharmacology and Therapeutics. 16: 369-372.

6 Chrubasik J., Warth L., Wüst H., Bretschneider H. \& Schulte-Mönting J. 1998. Untersuchung zur analgetischen Wirksamkeit peridural applizierten tramadols bei der behandlung von schmerzen nach abdominalchirurgischen Eingriffen. Schmerz Pain Douleur. 9: 12-18.

7 Coda B.A., Hill H.F., Schaffer R.L., Luger T.J., Jacobson R.C. \& Chapman C.R. 1993. Enhancement of morphine analgesia by fenfluramine in subjects receiving tailored opioid infusions. Pain. 52: 85-91.

8 Collart L., Luthy C. \& Dayer P. 1993. Multimodal analgesic effect of tramadol. Clinical Pharmacology and Therapeutics. 53: 223.

9 Driessen B. \& Reimann W. 1992. Interaction of the central analgesic, tramadol, with the uptake and release of 5hydroxytryptamine in the rat brain in vitro. British Journal of Pharmacology. 105: 147-151.

10 Driessen B., Reimann W. \& Giertz H. 1993. Effects of the central analgesic tramadol on the uptake and release of noradrenaline and dopamine in vitro. British Journal of Pharmacology. 108: 806-811.

11 Eggers K.A. \& Power I. 1995. Tramadol. British Journal of Anaesthesia. 74: 247-249.

12 Gordon N.C., Heller P.H. \& Levine J.D. 1992. Enhancement of pentazocine analgesia by clonidine. Pain. 48: 67-169.

13 Hellyer P.W. \& Gaynor J.S. 1998. Acute postsurgical pain in dogs and cats. Compendium on Continuing Education for the Practicing Veterinarian. 20: 140-153.

14 Houmes R.J.M., Voets M.A., Verkaaik A., Erdmann W. \& Lachmann B. 1992. Efficacy and safety of tramadol versus morphine for moderate and severe postoperative pain with special regard to respiratory depression. Anesthesia \& Analgesia. 74: $510-514$.

15 Ilkiw J.E. 1999. Balanced anesthetic techniques in dogs and cats. Clinical Techniques in Small Animal Practice. 14: 27-37.

16 Lee C.R., McTavish K. \& Sorkin E.M. 1993. Tramadol: A preliminary review of its pharmacology and pharmacokinetic properties, and therapeutic potential in acute and chronic pain states. Drugs. 46: 314-340. 
17 Mathews K.A. 2000. Pain assessment and general approach to management. EUA: Veterinary Clinics of North America. Small Animal Practice. 30: 729-755.

18 Natalini C.C. \& Robinson E.P. 2000. Evaluation of the analgesic effects of epidurally administered morphine, alfentanil, butorphanol, tramadol and U50488H in horses. American Journal of Veterinary Research. 61: 1579-1586.

19 Osterloh G., Friederichs E., Felgenhauer F., Gunzler E.A., Henmi Z., Kitano T., Nakamura M., Hayashi H. \& Ishii I. 1978. General pharmacological studies on tramadol, a potent analgesic agent. Arzneimittelforschung. 28: 135-151.

20 Ozcengiz D., Gunduz M., Ozbek H. \& Isik G. 2001. Comparison of caudal morphine and tramadol for postoperative pain control in children undergoing inguinal herniorrhaphy. Paediatric Anaesthesia. 11: 459-464.

21 Paddleford R.R. 1999. Analgesia and pain management. In: Manual of Small Animal Anesthesia. 2nd edn. Philadelphia: W.B. Saunders, pp.227-246.

22 Pang W.W., Huang P.Y., Chang D.P. \& Huang M.H. 1999. The peripheral analgesic effect of tramadol in reducing propofol injection pain: A comparison with lidocaine. Regional Anesthesia and Pain Medicine. 24: 246-249.

23 Pang W.W., Mok M.S., Chang D.P. \& Huang M.H. 1998. Local anesthetic effect of tramadol, metoclopramide, and lidocaine following intradermal injection. Regional Anesthesia and Pain Medicine. 23: 580-583.

24 Raffa R.B., Friederichs E., Reimann W., Shank R.P., Codd E.E., Vaught J.L., Jacoby H.I. \& Selve N. 1993. Complementary and synergistic antinociceptive interaction between the enantiomers of tramadol. Journal of Pharmacology and Experimental Therapeutics. 267: 331-340.

25 Raffa R.B., Riderichs E., Reimann W., Shank R.P., Codd E.E. \& Vaught J.L. 1992. Opioid and non-opioid components independently contribute to the mechanism of action of tramadol: an 'atypical' opioid analgesic. Journal of Pharmacology and Experimental Therapeutics. 260: 275-285.

26 Sawynok J. 1989. The role of ascending and descending noradrenergic and serotonergic pathways in opioid and non-opioid antinociception as revealed by lesion studies. Canadian Journal of Physiology and Pharmacology. 67: 975-988.

27 Senel A.C., Akyol A., Dohman D. \& Solak M. 2001. Caudal bupivacaine-tramadol combination for postoperative analgesia in pediatric herniorrhaphy. Acta Anaesthesiologica Scandinavica. 45: 786-789.

28 Steffey E.P., Gillespie J.R., Berry J.D., Eger II E.I. \& Rhode E.A. 1975. Circulatory effects of halothane and halothanenitrous oxide anesthesia in the dog: Spontaneous ventilation. American Journal of Veterinary Research. 36: $197-200$.

29 Thurmon J.C. \& Benson G.J. 1987. Pharmacologic consideration in selection of anesthetics for animals. Journal of American Veterinary Medical Association. 191: 1245-1251.

30 Wilder-Smith C.H., Wilder-Smith O.H.G., Farschtschian M. \& Naji P. 1998. Preoperative adjuvant epidural tramadol: the effect of different doses on postoperative analgesia and pain processing. Acta Anaesthesiologica Scandinavica. 42: 299-305.

31 Wong W.H. \& Cheong K.F. 2001. Role of tramadol in reducing pain on propofol injection. Singapore Medical Journal. 42: 193-195.

32 Yaksh T.L. \& Wilson P.R. 1979. Spinal serotonin terminal system mediates antinociception. Journal of Pharmacology and Experimental Therapeutics. 208: 446-453. 